Arq. Bras. Med. Vet. Zootec., v.72, n.3, p.921-925, 2020

\title{
Cutaneous metastatic melanoma in a Siberian tiger (Panthera tigris altaica) - case report
}

[Melanoma cutâneo metastático em um tigre-siberiano (Panthera tigris altaica) - relato de caso]

\author{
C. Eckstein ${ }^{1}$, H.P. Tinoco ${ }^{2}$, C.M. Coelho ${ }^{2}$, P.A. Lima ${ }^{1}$, C.E.V. Rocha ${ }^{3}$, R.L. Santos ${ }^{1 *}$ \\ ${ }^{1}$ Escola de Veterinária - Universidade Federal de Minas Gerais - Belo Horizonte, MG \\ ${ }^{2}$ Fundação Zoo-Botânica de Belo Horizonte - Belo Horizonte, MG \\ ${ }^{3}$ Instituto de Ciências Biológicas - Universidade Federal de Minas Gerais - Belo Horizonte, MG
}

\begin{abstract}
A male 15-year-old captive Siberian tiger (Panthera tigris altaica) developed pelvic limb hypermetry over the past 10 years. Recently, an ulcerated black nodule located caudally to the right ear was observed. The animal was submitted to surgery for removing the tumor, but died during anesthetic recovery. At necropsy, another infiltrative nodule was observed caudally to the right ear. Histologically, both nodules corresponded to melanocytic neoplasia, varying from heavily pigmented to amelanotic, with metastasis to mediastinal lymph nodes, spleen and lung. Lipofuscinosis and corpora amylacea were histologically observed in the central nervous system. Macroscopic and histologic findings confirmed the diagnosis of skin metastatic melanoma in a captive adult Siberian tiger.
\end{abstract}

Keywords: melanocytic neoplasia, wild animals, cutaneous melanoma, captive felines

\section{RESUMO}

Um tigre-siberiano (Panthera tigris altaica) de cativeiro, macho, de 15 anos de idade, apresentou hipermetria dos membros pélvicos nos últimos 10 anos, e recentemente, foi observado um nódulo preto e ulcerado caudalmente à orelha direita. $O$ animal foi submetido à cirurgia para remoção do nódulo e morreu durante a recuperação anestésica. À necropsia, outro nódulo infiltrativo, foi detectado caudalmente a orelha direita. Histologicamente, ambos os nódulos correspondiam à neoplasia melanocítica, com células variando de fortemente pigmentadas a amelanóticas, com metástase para linfonodos mediastinais, baço e pulmão. Havia lipofucsinose e corpora amilácea no sistema nervoso central. Os achados macroscópicos e histológicos confirmam o diagnóstico de melanoma cutâneo metastático em um tigre-siberiano adulto de cativeiro.

Palavras-chave: neoplasia melanocítica, animais silvestres, melanoma cutâneo, felinos de cativeiro

\section{INTRODUCTION}

Occurrence of neoplasms in wild felines has been poorly studied, with a few publications based on necropsy surveys of zoo animals (Lombard and Witte, 1959; Owston et al., 2008) or, rarely, based on free-living animals (Effron et al., 1977). Previously reported neoplasms affecting Siberian tigers (Pathera tigris altaica), also known as Amur tiger, include pulmonary adenoma (Effron et al., 1977), odontogenic tumor (Fecchio et al., 2015), pancreatic adenocarcinoma, and Brunner's gland adenoma (Gombac et al., 2015). There are additional cases of neoplasms in Panthera tigris (without subspecies classification), including mammary adenocarcinoma, leiomyoma, uterine adenocarcinoma, squamous cell carcinoma, mastocytoma, parathyroid adenoma, lymphangioma, and sebaceous adenoma (Owston et al., 2008), whereas melanocytic neoplasms were not found in the literature affecting this species.

Recebido em 24 de setembro de 2017

Aceito em 20 de dezembro de 2017

*Autor para correspondência (corresponding author)

E-mail: rsantos@vet.ufmg.br 
Melanomas are neoplasms of neuroectodermal origin that synthesize variable amount of brown pigment that accumulates in the cytoplasm of cells. The prognostic of this neoplasm is quite variable, and it is commonly associated with the clinical stage, the response to treatment, localization, gross and histologic features (Smedley et al., 2011). Melanomas are considered common in humans and domestic dogs, rare in domestic cats (Patnaik and Mooney, 1988), and to the best of our knowledge there are no previous reports of melanocytic neoplasms affecting Siberian tigers. This report aimed to describe gross and histological changes of a captive Siberian tiger (Panthera tigris altaica) with metastatic melanoma.

\section{CASE REPORT}

A 15 year-old male Siberian tiger (Panthera tigris altaica) kept in captivity at the Zoological Garden in Belo Horizonte (Brazil), presented hypermetry of hind limbs over a period of 10 years. The tiger developed a cutaneous pigmented nodule located caudally to the right ear, which grew rapidly. In December 2016, the tiger was subjected to surgery for removing the nodule, but died after the procedure (during anesthetic recovery), and was submitted to necropsy. The nodule that has been surgically removed was sent to histologic evaluation.

Grossly, there were several whitish firm nodules ranging from 2 to $5 \mathrm{~mm}$ diffusely distributed in the pulmonary parenchyma. Similar nodules were observed in the spleen, ranging from 0.5 to $2.0 \mathrm{~cm}$ diffusely distributed in the parenchyma, with moderate splenomegaly. Mediastinal lymph nodes were diffusely black. In the thyroid, there were numerous cysts, ranging from 1 to $10 \mathrm{~mm}$, containing translucent liquid. The liver was diffusely yellow, unctuous and friable.
Adjacent to the site of surgical removal of the neoplastic nodule, there was other solid, firm, black nodule, with $8 \mathrm{~cm}$ in diameter, infiltrating the adjacent tissue and with intense vascularization. There were no gross changes in the central nervous system. Tissue samples from the cutaneous nodule removed at surgery and the nodule found at necropsy, as well as samples of the central nervous system (brain and spinal cord), stomach, spleen, kidney, lymph nodes, liver, heart, and lung, were collected fixed by immersion in $10 \%$ buffered formalin, and processed for histopathology. Three- $\mu \mathrm{m}$ sections were stained with hematoxylin and eosin (HE) and evaluated under light microscopy. Selected sections of the central nervous system were stained with the Periodic Acid-Shiff (PAS) staining.

Histologically, the nodule removed surgically was solid, invasive, not encapsulated, poorly demarcated, and composed of a dense cell population. Numerous cells contained brown granular intracytoplasmic pigment in variable amounts, ranging from heavily pigmented to amelanotic, with morphology consistent with melanocytes. Neoplastic cells were predominantly polygonal, with marked anisocytosis and anisokaryosis, sustained by a moderate amount of connective tissue. There were up to three mitotic figures per higher magnification field (Figure 1). There were numerous neoplastic cells with karyorrhexis and cariomegaly, atypical mitosis, and vascular invasion. Neoplastic cells were observed in the white nodules macroscopically identified in the spleen and mediastinal lymph nodes. Neoplastic cells were also observed in the periphery of blood vessels of the lung, forming agglomeration of cells, and in alveolar septa and terminal bronchioles, associated to moderate multifocal edema in alveoli. 




Figure 1. Melanoma in a Siberian tiger (Panthera tigris altaica). The neoplasm is densely cellular, solid, with moderate amount of connective stroma. Neoplastic cells containing variable amount of brown pigment in the cytoplasm (intensely pigmented to amelanotic), high mitotic index, marked anisocytosis and anisokaryosis, and vascular invasion (arrow). Hematoxylin and eosin, Bar=50 $\mu \mathrm{m}$.

In the cytoplasm of neurons of the brain and spinal cord, there was an accumulation of an orange pigment, compatible with lipofuscin. There were also rounded, basophilic, acellular structures ranging from 5 to $30 \mu \mathrm{m}$ in diameter in the neuropil of white and gray matter and, in lesser numbers, within the cytoplasm of neurons. These structures were PAS-positive and therefore compatible with corpora amylacea (Figure 2).



Figure 2. Brain. A) neuronal lipofuscinosis, and amorphous basophilic structures in the neuropil (arrow). Hematoxylin and eosin, Bar $=50 \mu \mathrm{m}$. B) stained positively by PAS and interpreted as corpora amylacea (arrow); asterisk indicates accumulation of PAS-positive material in the neuron cytoplasm with lipofuscinosis. PAS, Bar $=100 \mu \mathrm{m}$. 
There was diffuse mineralization in the middle portion of gastric mucosa. Additional lesions included moderate multifocal hemorrhage adjacent to the glomeruli at the medullar-cortical junction in the kidneys; intense diffuse follicular hyperplasia with accumulations of colloid in the thyroids; diffuse moderate hepatic lipidosis; and a mild multifocal thickening of the middle and intima in arterioles of the myocardium, with accumulation of non cellular, eosinophilic and amorphous material with rare macrophages.

\section{DISCUSSION}

Melanoma is a neoplasm commonly associated to unfavorable prognosis in domestic animals. It is common in dogs and less frequent in domestic cats (Smith et al., 2002). Melanoma has been rarely reported in wild felids (Cagnini et al., 2012; Steeil et al., 2013), but there were no previous reports of this neoplasm in Siberian tigers (Panthera tigris altaica) so to the best or our knowledge this is the first report of a melanocytic tumor in this species.

In contrast to domestic dogs, in which the oral mucosa followed by the skin are the most common sites of melanoma, the ocular bulb is the most common site in felines, followed by the skin (Patnaik and Mooney, 1988), particularly the skin of the head (Chamel et al., 2017). There are two previous reports of melanocytic neoplasms in African lions (Panthera leo) affecting the ocular bulb and the upper lip (Cagnini et al., 2012; Steeil et al., 2013), but there are no reports of cutaneous melanocytic tumors in wild felids. Although cutaneous melanocytic tumors are not frequent in felines, in this case, cells containing brown pigment allowed the diagnosis based on HE-stained sections.

Cutaneous melanocytic tumors in human patients has intermittent exposure of solar ultraviolet rays (UV) as a major risk factor (Pinault et al., 2017), due to its damage on the genetic material of cells (Rastrelli et al., 2014). In animals, the risk of sun exposure for melanomas occurrence has been hypothesized based on human studies, but the association between sun exposure and melanoma in animals lacks scientific confirmation. Incidence of melanoma increases significantly with age in humans (Rastrelli et al., 2014) and in domestic cats (Patnaik and Mooney, 1988). Therefore, considering the increased longevity of captive wild animals (Cagnini et al., 2012), age predisposition may be an important factor in captivity.

In domestic cats, intraocular and oral melanomas are considered with higher potential of malignancy when compared to cutaneous melanocytic tumors (Patnaik and Mooney, 1988). However, in the present report, the high mitotic index, the intense cellular and nuclear pleomorphism, as the presence of atypical neoplastic cells indicate the high degree of malignancy of this tumor in this animal. Importantly, one of the criteria for defining malignancy in melanocytic tumors is the presence of at least three mitoses in 10 fields of high magnifications (Smith et al., 2002), whereas in this case there were up to three mitoses per field.

The occurrence of neurological signs can be associated with the presence of neuronal lipofuscin and corpora amylacea evidenced in this case. Nonetheless, these changes are commonly is associated to advance of age (Márquez et al., 2010; Wohlsein et al., 2013), due to cellular aging process, chronic and debilitating diseases. In conclusion, this in the first report of melanocytic tumor in Siberian tiger. The changes found in the central nervous system of the animal were not related to the tumor lesions observed in this case, although possibly they were of clinical importance.

\section{ACKNOWLEDGEMENT}

Work in RLS lab is supported by $\mathrm{CNPq}$ (Conselho Nacional de Desenvolvimento Científico e Tecnológico, Brazil), FAPEMIG (Fundação de Amparo a Pesquisa do Estado de Minas Gerais, Brazil), and CAPES (Coordenação de Aperfeiçoamento de Pessoal de Nível Superior, Brazil). TAP and RLS have fellowships from CNPq (Brazil). 


\section{REFERENCES}

CAGNINI, D.Q.; SALGADO, B.S.; LINARDI, J. L. et al. Ocular melanoma and mammary mucinous carcinoma in an African lion. BMC Vet. Res., v.8, p.176, 2012.

CHAMEL, G.; ABADIE, J.; ALBARIC, O. et al. Non-ocular melanomas in cats: a retrospective study of 30 cases. J. Feline Med. Surg., v.19, p.351-357, 2017.

EFFRON, M.; GRINER, L.; BENIRSCHKE, K. Nature and rate of neoplasia found in captive wild mammals, birds, and reptiles at necropsy. $J$. Natl. Cancer Inst., v.59, p.185-198, 1977.

FECCHIO, R.S.; GOMES, M.D.S.; XAVIER, J.G. et al. Maxillary calcifying epithelial odontogenic tumor in a Siberian tiger (Panthera tigris altaica). J. Vet. Dent., v.32, p.120-121, 2015.

GOMBAC, M.; DOLENSEK, T.; JAUSOVEC, D. et al. Simultaneous occurrence of pancreatic adenocarcinoma and Brunner's gland adenoma in a Siberian tiger (Panthera tigris altaica). $J$. Comp. Pathol., v.153, p.363-367, 2015.

LOMBARD, L.S.; WITTE, E.J. Frequency and types of tumors in mammals and birds of the Philadelphia Zoological Garden. Cancer Res., v.19, p.127-141, 1959.

MÁRQUEZ, M.; PÉREZ, L.; SERAFÍN, A. et al. Characterisation of Lafora-like bodies and other polyglucosan bodies in two aged dogs with neurological disease. Vet. J. v.183, p.222-225, 2010.

OWSTON, M.A.; RAMSAY, E.C.; ROTSTEIN, D.S. Neoplasia in felids at the Knoxville Zoological Gardens, 1979-2003. J. Zoo Wildl. Med., v.39, p.608-613, 2008.
PATNAIK, A.K.; MOONEY, S. Feline melanoma: a comparative study of ocular, oral, and dermal neoplasms. Vet. Pathol., v.25, p.105112, 1988.

PINAULT, L.; BUSHNIK, T.; FIOLETOV, V. et al. The risk of melanoma associated with ambient summer ultraviolet radiation. Health Rep., v.28, p.3-11, 2017.

RASTRELLI, M.; TROPEA, S.; ROSSI, C.R. et al. Melanoma: Epidemiology, risk factors, pathogenesis, diagnosis and classification. In Vivo, v.28, p.1005-1011, 2014.

SMEDLEY, R.C.; SPANGLER, W.L.; ESPLIN, D.G. et al. Prognostic markers for canine melanocytic neoplasms: a comparative review of the literature and goals for future investigation. Vet. Pathol., v.48, p.54-72, 2011.

SMITH, S.H.; GOLDSCHMIDT, M.H.; MCMANUS, P.M. A comparative review of melanocytic neoplasms. Vet. Pathol., v.39, p.651-678, 2002.

STEEIL, J.C.; SCHUMACHER, J.; BAINE, K. et al. Diagnosis and treatment of a dermal malignant melanoma in an African lion (Panthera leo). J. Zoo Wildl. Med., v.44, p.721727, 2013.

WOHLSEIN, P.; DESCHL, U.; BAUMGARTNER, W. Nonlesions, unusual cell types, and postmortem artifacts in the central nervous system of domestic animals. Vet. Pathol., v.50, p.122-143, 2013. 